\title{
Eubacterium cylindroides (Rocchi) Holdeman and Moore: Emended Description and Designation of Neotype Strain
}

\author{
ELIZABETH P. CATO, CAROLYN W. SALMON, and LILLIAN V. HOLDEMAN
}

Anaerobe Laboratory, Virginia Polytechnic Institute and State University, Blacksburg, Virginia 24061

\begin{abstract}
Twenty-five strains that conform closely to the original and subsequent descriptions of the organism now known as Eubacterium cylindroides (Rocchi) Holdeman and Moore have been studied, and previously undescribed characteristics of this species are presented. This organism is a numerically significant member of the normal intestinal flora of man and animals, and it has also been found in clinical specimens. ATCC 27803 (=Virginia Poly technic Institute 3654) is designated the neotype strain of Eubacterium cylindroides.
\end{abstract}

In 1908 , G. Rocchi isolated from the feces of a normal human adult an organism which he named Bacterium cilindroide (sic) (8). $\mathrm{He}$ described it as a large filamentous rod, 6 to 8 $\mu \mathrm{m}$ in length, with swellings and granules, sometimes having the appearance of tortuous noodles. It did not stain uniformly and was gram-negative. It was a strict anaerobe and grew slowly and only in the presence of a fermentable carbohydrate. The temperature for optimum growth was $38 \mathrm{C}$. It did not grow on the surface of agar, but in deep agar the colonies were small and roundish with no distinctive characteristics. Milk was not changed, albumins were not attacked, and proteoses were slightly attacked. Glucose and sucrose were weakly acidified; there was no action on lactose, galactose, mannitol, or dulcitol. It was nonpathogenic.

This group of organisms was renamed Ristella cylindroides by Prévot in 1938 (7), who added to the description the information that gelatin was not liquefied and gas and spores were not produced. In Krasil'nikov's classification (4), this organism was named Pseudobacterium cylindroides. Another synonym for this organism is Bacteroides cylindroides (Rocchi) Kelly (3).

The strain on which the original description of this organism was based is not extant, and there are no strains of this organism in Prévot's collection at the Pasteur Institute (Paris). Possibly no isolates have been reported because of a typographical error which has persisted from at least as far back as 1937 (9), when it was stated that the organism only grew at $18 \mathrm{C}$. As originally described, best growth occurred at $38 \mathrm{C} \mathrm{(8).}$

Many strains that possess the morphological characters given in the original description of this organism (8) have been isolated in our laboratory. Organisms in this group do not stain uniformly with the Gram stain. They are often gram-negative in 24-h-old cultures. However, young (2- to 4-h-old) cultures of the same strains are actually gram-positive but decolorize readily. The major products of fermentation by these strains are lactic and butyric acids, sometimes with acetic, formic, and succinic acids. Because they are anaerobic, gram-positive, non-sporeforming rods that produce butyric and other acids, they were reclassified as Eubacterium cylindroides $(2,6)$.

On the basis of a study of 25 strains whose characters conform closely with those given in the original description of $B$. cilindroide Rocchi (8), the description has been emended and a neotype strain selected.

\section{MATERIALS AND METHODS}

Bacterial strains. The 25 strains included in this study were isolated in our laboratory: 19 were from feces of clinically normal humans, two were from chicken intestinal contents, one was from the intestine of a hog, one was a contaminant in a Pasteur Institute (Paris) culture labeled Staphylococcus anaerobius from pus from an inguinal cyst, and two were isolated as the only organisms detected from the blood of a patient with congestive heart failure and acute myocardial infarction. Both strains from this patient were included in this study, since only one fermented sucrose and the other fermented inulin; there were also slight differences in their colony types.

Methods. The methods for the isolation and characterization of these organisms have been described previously (2). The thermal melting point method of Marmur and Doty (5) was used for determination of the guanine + cytosine $(G+C)$ 
content of the deoxyribonucleic acid (DNA) preparations.

\section{RESULTS AND DISCUSSION}

Morphologically (Fig. 1), the cells of Eubacterium cylindroides are as originally described (8): they are rather pleomorphic rods with granules and swellings; they occur singly, in pairs, or in short chains; they may be straight or curved with tapered or rounded ends; they do not stain uniformly, and, although gram-positive in young cultures, they rapidly become gram-negative; they are nonmotile and measure 0.3 to 1.2 by 0.8 to $50.0 \mu \mathrm{m}$. Filamentous forms are often seen.

Surface colonies on blood agar plates ( 2 days) are pinpoint to $2 \mathrm{~mm}$ in diameter, circular to slightly irregular, entire to diffuse, convex, translucent to opaque, and often have a mottled or granular appearance when viewed by obliquely transmitted light. Some strains are slightly hemolytic on sheep blood agar.

Glucose broth cultures are turbid with a smooth or ropy sediment. The average $\mathrm{pH}$ after 5 days of incubation is 5.2 compared to 6.1 in a basal noncarbohydrate medium. The organisms are strict anaerobes, and growth is stimulated in the presence of a fermentable carbohydrate as stated in the original description. The temperature for optimal growth is $37 \mathrm{C}$, although most strains grow equally well at $45 \mathrm{C}$.

Biochemical reactions of the strains studied are listed in Table 1. In addition, neither lecithinase nor lipase was formed on McClungToabe egg yolk agar; catalase and deoxyribonuclease were not present; hippurate was not hydrolyzed; indole was not formed, and nitrate was not reduced; acetylmethylcarbinol was formed by 8 of 21 strains tested; little or no gas was produced in glucose agar deeps; neither $\mathrm{H}_{2}$ nor increased $\mathrm{CO}_{2}$ was present in the head space above fructose broth cultures inoculated under $\mathrm{N}_{2} ; \mathrm{H}_{2} \mathrm{~S}$ was not formed, but ammonia was produced by some strains; and all strains

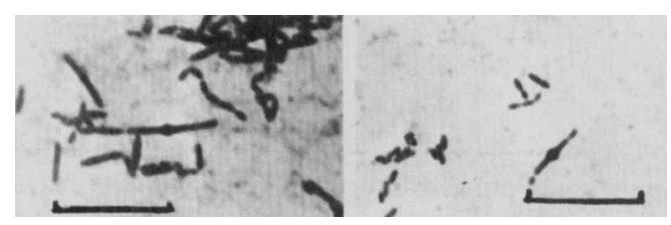

FIG. 1. E. cylindroides ATCC 27803. Cells from a 24-h-old peptone-yeast extract-glucose agar slant (left); cells from a 24-h-old sweet $E$ (2) agar slant (right). Bars represent $10 \mu \mathrm{m}$.
TABLE 1. Biochemical reactions of strains of E. cylindroides $^{a}$

\begin{tabular}{|c|c|c|c|c|c|}
\hline $\begin{array}{l}\text { Substrate or } \\
\text { reaction }\end{array}$ & Rocchi & $\begin{array}{l}\text { No. } \\
\text { strains } \\
\text { tested }\end{array}$ & $\begin{array}{l}\text { Test } \\
\text { result }\end{array}$ & $\%+$ & $\begin{array}{l}\text { Neo- } \\
\text { type } \\
\text { strain }\end{array}$ \\
\hline Cellobiose & & 25 & $-w$ & 32 & - \\
\hline Dulcitol & - & 25 & - & 0 & - \\
\hline Fructose & & 25 & A & 100 & A \\
\hline Galactose & - & 19 & - & 0 & - \\
\hline Glucose & w & 25 & A & 100 & $\mathrm{~A}$ \\
\hline Inulin & & 18 & A- & 61 & A \\
\hline Lactose & - & 25 & - & 0 & - \\
\hline Maltose & & 25 & - & 0 & - \\
\hline Mannitol & - & 25 & - & 0 & - \\
\hline Mannose & & 25 & Aw & 100 & A \\
\hline Raffinose & & 25 & $-\mathbf{w}$ & 44 & - \\
\hline Salicin & & 25 & $\mathrm{~A}-$ & 72 & - \\
\hline Sucrose & w & 25 & A- & 64 & A \\
\hline Trehalose & & 25 & $-A$ & 12 & - \\
\hline $\begin{array}{l}\text { Starch hydro- } \\
\text { lyzed }\end{array}$ & & 25 & -+ & 28 & - \\
\hline $\begin{array}{l}\text { Esculin hydro- } \\
\text { lyzed }\end{array}$ & & 25 & + & 100 & + \\
\hline $\begin{array}{l}\text { Gelatin lique- } \\
\text { fied }\end{array}$ & - & 22 & - & 0 & - \\
\hline Milk changed & - & 24 & - & 0 & - \\
\hline
\end{tabular}

${ }^{a}$ No strain fermented arabinose, ribose, xylose, ery thritol, glycerol, inositol, sorbitol, amygdalin, dextrin, esculin, glycogen, melezitose, melibiose, rhamnose, or sorbose. Two weakly fermented starch. Where a single result is listed, the reaction is produced by $390 \%$ of the cultures. Where two reactions are listed, the first is the result observed with most cultures, the second is less frequently observed. Legend: $+=$ reaction positive, $-=$ reaction negative or $\mathrm{pH}>6.0, \mathrm{w}=$ pH 5.5 to $6.0, \mathrm{~A}=\mathrm{pH}<5.5$.

reduced neutral red, but only 12 of the 25 reduced resazurin.

Products of fermentation of peptone-yeast extract-glucose broth include DL-lactic acid ( 1.0 to $8.9 \mathrm{meq} / 100 \mathrm{ml}$ ), butyric acid $(0.4$ to $2.6 \mathrm{meq} / 100 \mathrm{ml}$ ), and occasionally traces of formic acid $(0.0$ to $0.7 \mathrm{meq} / 100 \mathrm{ml})$ and succinic acid $(0.0$ to $0.5 \mathrm{meq} / 100 \mathrm{ml})$. Neither threonine, lactate, gluconate, glucuronate, nor galacturonate was utilized, but pyruvate was converted to acetate, butyrate, and formate.

Reactions of individual representative strains of this species are listed in Table 2. The G+C content of the DNA of three of these representative strains was 26,31 , and $35 \mathrm{~mol} \%$, indicating that there may be heterogeneity within this group of organisms. However, strain ATCC 27805 , giving a low $\mathrm{G}+\mathrm{C}$ value of only $26 \%$, also yielded little DNA. Thus, this result may be questionable. Other reactions did not differ and are as described above. Strain 
(Virginia Polytechnic Institute) 0689B was isolated from the anterior small intestine of a hog, VPI 1278 from the cecum of a chicken, strains ATCC 27803, 27804, and 27805 were from feces of clinically normal humans, and strain ATCC 27528 was from the blood of a patient with congestive heart failure. ATCC 27803 (= VPI 3654) is here designated the neotype strain of E. cylindroides (Rocchi) Holdeman and Moore.
Characteristics which qualify $E$. cylindroides as a member of the genus Eubacterium Prévot: $E$. cylindroides is a member of the genus Eubacterium because it is an obligately anaerobic, gram-variable, non-sporeforming rod whose major fermentation products are lactic and butyric acids (6).

Those characteristics most useful in distinguishing $E$. cylindroides from other members of the genus Eubacterium are shown in Table 3.E.

TABLE 2. Reactions of representative strains of $E$. cylindroides

\begin{tabular}{l|l|l|c|c|c|c}
\hline & \multicolumn{5}{|c}{ Strain } \\
\cline { 2 - 6 } $\begin{array}{c}\text { Substrates and } \\
\text { products }\end{array}$ & VPI 0689B & VPI 1278 & $\begin{array}{c}\text { ATCC 27804, } \\
\text { VPI 3651 } \\
(35 \% \mathrm{G}+\mathrm{C})\end{array}$ & $\begin{array}{c}\text { ATCC 27803, } \\
\text { VPI 3654 } \\
(31 \% \mathrm{G}+\mathrm{C})\end{array}$ & $\begin{array}{c}\text { ATCC 27805, } \\
\text { VPI 3696 } \\
(26 \% \mathrm{G}+\mathrm{C})\end{array}$ & $\begin{array}{c}\text { ATCC 27528, } \\
\text { VPI 6849A }\end{array}$ \\
\hline PY $^{a}$ & $6.03^{b}$ & 6.0 & 6.1 & 6.1 & 6.15 & 6.1 \\
Cellobiose & 5.8 & 6.1 & 6.0 & 6.1 & 6.1 & 5.5 \\
Fructose & 5.3 & 4.85 & 5.2 & 5.1 & 5.0 & 5.3 \\
Glucose & 5.45 & 5.1 & 5.1 & 5.1 & 5.35 & 5.3 \\
Inulin & 5.8 & 5.7 & 5.1 & 6.0 & 5.85 & 5.6 \\
Mannose & 5.7 & 5.0 & 5.15 & 5.3 & 5.1 & 5.55 \\
Raffinose & 5.5 & 6.0 & 6.0 & 6.05 & 6.6 & 5.65 \\
Salicin & 5.5 & 6.1 & 6.0 & 6.1 & 5.45 & 5.5 \\
Sucrose & 5.5 & 5.6 & 6.1 & 5.05 & 6.2 & 5.45 \\
Trehalose & 5.45 & 6.2 & 6.3 & 6.1 & LB & LBf \\
Products-PYG & LBfs & LB & LB & LB & & \\
\hline
\end{tabular}

${ }^{a}$ PY, Peptone-yeast ex tract; PYG, peptone-yeast extract-glucose.

$b$ pH after 5-day incubation.

$c_{\mathrm{L}}=$ at least $1 \mathrm{meq}$ lactic acid $/ 100 \mathrm{ml} ; \mathrm{B}=$ at least $1 \mathrm{meq}$ butyric acid $/ 100 \mathrm{ml} ; \mathrm{f}=\langle 1$ meq formic acid $/ 100 \mathrm{ml}$; $\mathrm{s}=\langle 1 \mathrm{meq}$ succinic acid $/ 100 \mathrm{ml}$.

TABLE 3. Characteristics that differentiate E. cylindroides from other species in the genus Eubacterium ${ }^{a}$

\begin{tabular}{|c|c|c|c|c|c|c|c|c|}
\hline $\begin{array}{c}\text { Eubacterium } \\
\text { species }\end{array}$ & $\begin{array}{l}\text { Butyric } \\
\text { produced }\end{array}$ & $\begin{array}{l}\text { Fructose } \\
\text { acid }\end{array}$ & $\begin{array}{l}\text { Mannose } \\
\text { acid }\end{array}$ & $\begin{array}{l}\text { Starch } \\
\text { acid }\end{array}$ & $\begin{array}{c}\text { Esculin } \\
\text { hydrolyzed }\end{array}$ & $\begin{array}{l}\text { Maltose } \\
\text { acid }\end{array}$ & $\begin{array}{l}\text { Lactose } \\
\text { acid }\end{array}$ & $\begin{array}{l}\text { Products } \\
\text { (PYG) }^{b}\end{array}$ \\
\hline E. cylindroides & + & + & + & - & + & - & - & $\mathrm{LB}(\mathrm{sf})$ \\
\hline E. multiforme & + & + & + & - & + & - & + & $\mathrm{LAB}(\mathrm{fsp})$ \\
\hline E. nitritogenes & + & + & + & -+ & + & + & -+ & LBAs(fp) \\
\hline E. moniliforme & + & + & + & -+ & - & $\mathrm{v}$ & - & $\mathrm{LBa}(\mathrm{fsp} 2)$ \\
\hline E. budayi & + & + & + & + & + & + & + & Lba \\
\hline E. rectale & + & + & $\mathrm{v}$ & + & + & + & + & $\mathrm{LB}(\mathrm{sfa})$ \\
\hline E. ruminantium & + & + & - & + & + & $\mathbf{v}$ & $\mathbf{v}$ & $\mathrm{LFb}(\mathrm{ap})$ \\
\hline E. tortuosum & + & + & - & - & + & + & $\mathbf{v}$ & $\operatorname{Lbs}(a f)$ \\
\hline E. cellulosolvens & + & - & + & - & + & + & - & $\operatorname{Lfbsa}(\mathrm{p})$ \\
\hline E. combesii & + & - & - & - & + & -+ & - & ABibivp \\
\hline E. tenue & - & -+ & - & -+ & - & -+ & - & Af(lspibiv) \\
\hline E. contortum & - & + & $\mathrm{v}$ & $\mathrm{v}$ & + & + & $\mathbf{v}$ & $\mathrm{Af}(\mathrm{sl} 2)$ \\
\hline E. aerofaciens & - & + & + & - & +- & + & +- & $\mathrm{LAF}(\mathrm{s} 2)$ \\
\hline E. lentum & - & - & - & - & - & - & - & (afsl) \\
\hline
\end{tabular}

${ }^{a}$ Adapted from Holdeman and Moore (2); Legend: $+=$ reaction positive for $190 \%$ of strains, $-=$ reaction negative for $190 \%$ of strains, $v=$ reaction positive for $40-60 \%$ of strains. Where two reactions are listed, the first is the result observed with most cultures, the second reaction less frequently observed.

$b$ Products: $\mathrm{L}=$ lactic acid; $\mathrm{B}=$ butyric acid; $\mathrm{S}=$ succinic acid; $\mathrm{F}=$ formic acid; $\mathrm{P}=$ propionic acid; $\mathrm{A}=$ acetic acid; 2 = ethyl alcohol; $\mathrm{ib}=$ isobutyric acid; iv = isovaleric acid; upper case $=11 \mathrm{meq} / 100 \mathrm{ml}$; lower case = $\langle 1 \mathrm{meq} / 100 \mathrm{ml} ;()$ = produced by some strains. $\mathrm{PYG}$, peptone-yeast extract-glucose. 
cylindroides produces butyric acid, hydrolyzes esculin, and acidifies glucose, fructose, and mannose, but not starch, maltose, or lactose.

Because $E$. cylindroides is easily decolorized, it may be confused with Fusobacterium prausnitzii $(\mathrm{mol} \% \mathrm{G}+\mathrm{C}=50$ to 57$)$; however, it is more fermentative than strains of $F$. prausnitzii.

\section{ACKNOWLEDGMENTS}

This investigation was supported by grant no. 14604 from the National Institute of General Medical Sciences.

We wish to thank J. L. Johnson for the determinations of DNA G+C mol\%.

\section{REPRINT REQUESTS}

Address reprint requests to: Elizabeth P. Cato, V.P.I. Anaerobe Laboratory, Post Office Box 49, Blacksburg, Va. 24060.

\section{LITERATURE CITED}

1. Buchanan, R. E., J. G. Holt, and E. F. Lessel, Jr., ed. 1966. Index Bergeyana. The Williams \& Wilkins Co., Baltimore.
2. Holdeman, L. V., and W. E. C. Moore, ed. 1972. Anaerobe laboratory manual. Virginia Polytechnic Institute Anaerobe Laboratory, Blacksburg.

3. Kelly, C. D. 1957. Genus I. Bacteroides Castellani and Chalmers. 1919, p. 424-436. In R. S. Breed, E. G. D. Murray, and N. R. Smith (ed.), Bergey's manual of determinative bacteriology, 7 th ed. The Williams \& Wilkins Co., Baltimore.

4. Krasil'nikov, N. A. 1949. Guide to the bacteria and actinomyces. Akad. Nauk. S.S.S.R., Moscow.

5. Marmur, J., and P. Doty. 1962. Determination of the base composition of deoxyribonucleic acid from its thermal denaturation temperature. J. Mol. Biol. 5:109-118.

6. Moore, W. E. C., and L. V. Holdeman. 1973. New names and combinations in the genera Bacteroides Castellani and Chalmers, Fusobacterium Knorr, Eubacterium Prévot, Propionibacterium Delwich, and Lactobacillus Orla-Jensen. Int. J. Syst. Bacteriol. 23:69-74.

7. Prévot, A. R. 1938. Études de systematique bactérienne. III. Invalidité du genre Bacteroides Castellani et Chalmers. Démembrement et réclassification. Ann. Inst. Pasteur, (Paris) 60:292.

8. Rocchi, G. 1908. Lo stato attuale delle nostre cognizioni sui germi anaerobi. Tossi-infezioni putride e gangrenose. Capitolo II. Bull. Sci. Med. 8:457-479.

9. Weinberg, M., R. Nativelle, and A. R. Prévot. 1937. Les microbes anaérobies. Masson and Co., Paris. 